$\mathrm{DE}$

M E D I C I N A

T R O P I C A L

$\mathrm{DE}$

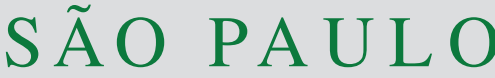

JOURNAL OF THE SÃO PAULO INSTITUTE OF TROPICAL MEDICINE

'Universidade Estadual Paulista (Unesp), Faculdade de Ciências Farmacêuticas, Araraquara, São Paulo, Brazil

2Universidade de São Paulo, Faculdade de Filosofia Ciências e Letras de Ribeirão Preto, Departamento de Química, Ribeirão Preto, São Paulo, Brazil

${ }^{3}$ Universidade Estadual de Maringá, Centro de Ciências da Saúde, Departamento de Ciências Básicas da Saúde, Maringá, Paraná, Brazil

${ }^{4}$ Universidade Estadual de Maringá, Centro de Ciências da Saúde, Departamento de Farmácia e Farmacologia, Maringá, Paraná, Brazil

Correspondence to: Raquel Regina Duarte Moreira

Universidade Estadual Paulista (Unesp), Faculdade de Ciências Farmacêuticas, Departamento de Princípios Ativos Naturais e Toxicologia, Rodovia Araraquara-Jaú, km 1, s/n, CEP 14801-903, Araraquara SP, Brazil

Tel: +55 1633016992

E-mail: moreirar@fcfar.unesp.br

Received: 10 September 2018

Accepted: 7 December 2018

\section{Antileishmanial activity of Melampodium divaricatum and Casearia sylvestris essential oils on Leishmania amazonensis}

\author{
Raquel Regina Duarte Moreira ${ }^{1}$, André Gonzaga dos Santos ${ }^{1}$, Flavio \\ Alexandre Carvalho', Caio Humberto Perego', Eduardo José Crevelin², \\ Antônio Eduardo Miller Crotti ${ }^{2}$, Juliana $\mathrm{Cogo}^{3}$, Mara Lane Carvalho Cardoso ${ }^{4}$, \\ Celso Vataru Nakamura ${ }^{3}$
}

\section{ABSTRACT}

Leishmaniasis is a disease that affects millions of people and it is an important public health problem. The drugs currently used for the treatment of leishmaniasis present undesirable side effects and low efficacy. In this study, we evaluated the in vitro activity of Melampodium divaricatum (MD-EO) and Casearia sylvestris (CS-EO) essential oils (EO) against promastigote and amastigote forms of Leishmania amazonensis. Sesquiterpenes E-caryophyllene (56.0\%), germacrene $\mathrm{D}(12.7 \%)$ and bicyclogermacrene $(9.2 \%)$ were identified as the main components of MD-EO, whereas E-caryophyllene (22.2\%), germacrene D (19.6\%) and bicyclogermacrene $(12.2 \%)$ were the main constituents of CS-EO. CS-EO and E-caryophyllene were active against promastigote forms of L. amazonensis ( $\mathrm{IC}_{50} 24.2,29.8$ and $49.9 \mu \mathrm{g} / \mathrm{mL}$, respectively). However, MD-EO, CS-EO and E-caryophyllene were more active against amastigote forms, with $\mathrm{IC}_{50}$ values of $10.7,14.0$, and $10.7 \mu \mathrm{g} / \mathrm{mL}$, respectively. $E$-caryophyllene presented lower cytotoxicity against macrophages J774-A1 $\left(\mathrm{CC}_{50}\right.$ of $\left.62.1 \mu \mathrm{g} / \mathrm{mL}\right)$ than the EO. The EOs and $E$-caryophyllene should be further studied for the development of new antileishmanial drugs.

KEYWORDS: Leishmania amazonensis. Melampodium divaricatum. Casearia sylvestris. E-caryophyllene

\section{INTRODUCTION}

Leishmaniasis is an important public health problem and it is estimated that 2 million new cases occur each year, with at least 15-20 million infected people worldwide $^{1,2}$. Leishmania is the protozoan parasite responsible for leishmaniasis which is manifested in visceral, mucocutaneous or cutaneous forms ${ }^{2,3}$.

Drugs currently recommended for leishmaniasis treatment include compounds such as pentavalent antimonials, amphotericin B, lipid formulations of amphotericin B (treatment of visceral leishmaniasis) and miltefosine, which is the only orally administered drug. However, there are some limitations regarding their toxicity, lack of efficacy, need and cost of hospitalization $\cos ^{4-6}$. Other problems such as re-emerging infectious diseases and resistance to currently used drugs are widely recognized as being of serious and immediate concern. Thus, it is imperative to search for new drugs against Leishmania parasites $^{7-9}$.

Plants and their metabolites are potential sources of new antiprotozoal drugs, and can contribute to overcome protozoan parasites drug resistance ${ }^{10-12}$. Many plant essential oils have demonstrated anti-Leishmania activity in vivo and in vitro against the promastigote and/or the amastigote forms ${ }^{13-16}$. 
Asteraceae and Salicaceae species have attracted special attention due to their therapeutic properties, such as anthelmintic, antiinflammatory, astringent, antihemorrhagic, antimicrobial, diuretic, analgesic and antispasmodic effects ${ }^{17-19}$. Many species of these families, such as Melampodium divaricatum (Rich. ex Rich.) DC. (Asteraceae) and Casearia sylvestris Swartz (Salicaceae) are aromatic and their essential oils have a large chemical complexity. M. divaricatum, popularly known as 'falsacalêndula', 'flor-amarela' or 'flor-de-ouro', occurs in Northeastern Brazil and is used in folk medicine as wound healing, diaphoretic and diuretic. The essential oil from the aerial parts of $M$. divaricatum showed antimicrobial activity against $S$. aureus and B. subtilis ${ }^{16}$. C. sylvestris occurs in Brazil and other countries of Latin America. In Brazil, it is known as 'guaçatonga', 'cafezinho-do-mato or 'erva-de-lagarto' and it is used in traditional medicine as antiophidic, antiulcer, anti-pyretic, anti-inflammatory and wound healing ${ }^{20}$. However, the antileishmanial activity of $M$. divaricatum and $C$. sylvestris essential oils has not been previously investigated to date. Thus, in this work, we report the in vitro antileishmanial activity of the essential oils obtained from the aerial parts of M. divaricatum and C. sylvestris leaves collected in Brazil and their main component $E$-caryophyllene.

\section{MATERIAL AND METHODS}

\section{Plant material}

The aerial parts of Melampodium divaricatum (Rich. ex Rich.) DC. (Asteraceae) and leaves of Casearia sylvestris Swartz (Salicaceae) were collected at "Medicinal Botanical Garden" of School of Pharmaceutical Sciences of Sao Paulo State University (UNESP), Araraquara, Sao Paulo State, Brazil (21 ${ }^{\circ} 48^{\prime} 51.4^{\prime \prime} \mathrm{S}$ and $\left.48^{\circ} 12^{\prime} 5.1^{\prime \prime} \mathrm{W}\right)$. A voucher specimen of $M$. divaricatum (HRCB 35294) and C. sylvestris (AGS 102) were deposited at the Herbarium Institute of Biosciences of the UNESP Rio Claro, Sao Paulo State, Brazil and Herbarium Maria E. P. Kauffman Fidalgo of the Botanical Institute of Sao Paulo, Brazil, respectively.

\section{Essential oil extraction and chemicals}

Casearia sylvestris essential oil was obtained by hydrodistillation of its leaves $(150 \mathrm{~g})$ for $4 \mathrm{~h}$ in a Clevengertype apparatus according to the procedure described in the European Pharmacopoeia ${ }^{21}$. M. divaricatum essential oil was obtained by Moreira et al. ${ }^{16}$. The EOs were stored in amber bottles and kept in the refrigerator at $4{ }^{\circ} \mathrm{C}$ until further analysis. The yields $(\mathrm{w} / \mathrm{w})$ were calculated from the weight of the fresh aerial parts and leaves of M. divaricatum ( $0.4 \%)$ and leaves of $C$. sylvestris (0.3\%). E-Caryophyllene was purchased from Sigma-Aldrich Co. (St. Louis, MO, USA).

\section{GC/MS analysis}

GC-MS analyses were carried out on a Shimadzu QP2010 Plus (Shimadzu Corporation, Kyoto, Japan) system equipped with an AOC-20i auto sampler. The column consisted of Rtx5MS (Restek Co., Bellefonte, PA, USA) fused-silica capillary (length $=30 \mathrm{~m}$, i.d. $=0.25 \mathrm{~mm}$, and film thickness $=0.25 \mu \mathrm{m}$ ). The electron ionization mass spectrometry (EI-MS) mode at $70 \mathrm{eV}$ was employed. Helium (99.99\%) at a constant flow of $1.0 \mathrm{~mL} / \mathrm{min}$ was the carrier gas. The injection volume was $0.1 \mu \mathrm{L}$ (split ratio of 1:10). The injector and the ion source temperatures were set at 240 and $280{ }^{\circ} \mathrm{C}$, respectively. The oven temperature program was the same as the one used for GC-FID. The mass spectra were registered with a scan interval of $0.5 \mathrm{~s}$ in the mass range of 40 to $600 \mathrm{Da}$. Essential oil was solubilized in hexane (chromatographic grade; Merck ${ }^{\circledR}$, Darmstadt, Germany) 1:100 (v/v).

\section{GC/FID analysis}

The essential oil of C. sylvestris (CS-EO) was analyzed by gas chromatography (GC) on a Hewlett-Packard G1530A 6890 gas chromatograph fitted with FID and a data-handling processor. An HP-5 (Hewlett-Packard, Palo Alto, CA, USA) fused-silica capillary column (length $=30 \mathrm{~m}$, i.d. $=0.25 \mathrm{~mm}$, and film thickness $=0.33 \mu \mathrm{m}$ ) was employed. The column temperature was programmed to rise from 60 to $240{ }^{\circ} \mathrm{C}$ at $3{ }^{\circ} \mathrm{C} / \mathrm{min}$ and then held at $240{ }^{\circ} \mathrm{C}$ for $5 \mathrm{~min}$. The carrier gas was $\mathrm{H}_{2}$ at a flow rate of $1.0 \mathrm{~mL} / \mathrm{min}$. The equipment was set to the injection mode; the injection volume was $0.1 \mu \mathrm{L}$ (split ratio of 1:10). The injector and detector temperatures were 240 and $280{ }^{\circ} \mathrm{C}$, respectively. The relative concentrations of the components were obtained by peak area normalization (\%). The relative areas were the average of triplicate GC-FID analyses.

\section{Compound identification}

Compounds were identified on the basis of their retention indices relative to a homologous series of $n$-alkanes $\left(\mathrm{C}_{8}-\mathrm{C}_{20}\right)$. To this end, an Rtx-5MS capillary column was employed under the same operating conditions as in the case of GC-FID. The retention index (RI) of each constituent was determined as described previously ${ }^{22}$. The chemical structures were computer-matched with the Wiley7, NIST08, and FFNSC1.2 spectral libraries of the 
GC-MS data system; their fragmentation patterns were compared with the literature data ${ }^{23}$.

\section{Antileishmanial activity}

\section{Parasites and cell culture}

Promastigote forms of L. amazonensis (WHOM/BR/75/ Josefa), which were originally isolated by Cesar Augusto Cuba-Cuba (Universidade de Brasilia, Brazil) from a human case of diffuse cutaneous leishmaniasis. Parasites were cultured at $25^{\circ} \mathrm{C}$ in Warren's medium (brain-heart infusion plus haemin and folic acid) supplemented with $10 \%$ heat-inactivated fetal bovine serum (FBS) (Gibco Invitrogen Corporation, New York, USA) in a tissue flask. Macrophages (J774-A1) were maintained in tissue flasks with RPMI-1640 (pH 7.2) (Gibco Invitrogen, Grand Island, NY, USA), added with sodium bicarbonate and L-glutamine (As annex), and supplemented with 10\% FBS (Gibco Invitrogen, Grand Island, NY, USA) at $37{ }^{\circ} \mathrm{C}$ in a $5 \% \mathrm{CO}_{2}$ atmosphere $^{24}$.

\section{Antiproliferative activity studies on promastigote forms}

For experiments, promastigote forms in the logarithmic phase $\left(1 \times 10^{6}\right.$ cells $\left./ \mathrm{mL}\right)$ were cultured on a 24 -well plate in Warren's medium supplemented with $10 \%$ of inactivated FBS in the presence or absence of different essential oils concentrations (1-100 $\mu \mathrm{g} / \mathrm{mL})$. Amphotericin B was used as positive control $(0.01-10 \mu \mathrm{g} / \mathrm{mL})$. After $72 \mathrm{~h}$ at $28^{\circ} \mathrm{C}$, cell growth was estimated using the colorimetric cell viability XTT assay (2,3-bis[2-methyloxy-4-nitro-5-sulfophenyl]2H-tetrazolium-5-carboxanilide) (Sigma Chemical Co., St. Louis, MO, USA). All experiments were performed in duplicate, and the results expressed as log number cells $/ \mathrm{mL}$ and as the percentage of growth inhibition concentration that inhibited cell growth in $50 \%\left(\mathrm{IC}_{50}\right)$ was determined by nonlinear regression analysis ${ }^{25}$.

\section{Activity against intracellular amastigote forms}

For the antiproliferative activity on intracellular amastigotes, peritoneal macrophages from healthy BALB/c mice were harvested and plated $\left(3 \times 10^{5}\right.$ cells $\left./ \mathrm{mL}\right)$ in a 24-well plate with round coverslips using RPMI medium supplemented with $10 \%$ FBS to adhere for $2 \mathrm{~h}$ at $37{ }^{\circ} \mathrm{C}$ in $5 \% \mathrm{CO}_{2}$. Adhered macrophages were infected with promastigotes in the stationary growth phase using a ratio $1: 7$ at $34{ }^{\circ} \mathrm{C}$ for $4 \mathrm{~h}$. Afterwards, non-interiorized parasites were removed and the infected culture was treated with different concentrations of essential oils (1 to $20 \mu \mathrm{g} / \mathrm{mL}$ ) at $34{ }^{\circ} \mathrm{C}$. Amphotericin B was used as a positive control (0.1-10 $\mu \mathrm{g} / \mathrm{mL})$. After $48 \mathrm{~h}$, the coverslips were washed, fixed with methanol and stained with Giemsa. By counting
200 cells under a light microscope (Olympus CX 31) the percentage of infected cells and number of intracellular amastigotes were estimated. The survival index (percentage of infected cells $\mathrm{x}$ number of amastigotes per cell) was calculated and $\mathrm{IC}_{50}$ values were then determined by nonlinear regression analysis ${ }^{25}$.

The activity against intracellular amastigote forms was compared with toxicity in macrophages, yielding the selectivity index (SI; ratio of the $\mathrm{CC}_{50}$ in J774-A1 and the $\mathrm{IC}_{50}$ in protozoa).

\section{Cytotoxicity assay}

A suspension of J774-A1 macrophages $\left(5 \times 10^{5} \mathrm{cells} / \mathrm{mL}\right)$ was seeded in 96-well microplates. The cells were allowed to attach for $24 \mathrm{~h}$ at $37{ }^{\circ} \mathrm{C}$ in a $5 \% \mathrm{CO}_{2}$ atmosphere. The medium was then replaced by different concentrations of essential oil (10-1,000 $\mu \mathrm{g} / \mathrm{mL})$. Amphotericin B was also evaluated $(0.1-10 \mu \mathrm{g} / \mathrm{mL})$. Cytotoxicity in J774-A1 macrophages was evaluated after $48 \mathrm{~h}$ using the standard MTT colorimetric assay ${ }^{26}$. The mitochondrial-dependent reduction of 3-(4.5-dimethylthiazol-2-yl)-2.5-diphenyltetrazolium bromide (MTT) to formazan was used to assess the possible cytotoxic effects of the test compounds on murine peritoneal macrophages ${ }^{26}$. The cytotoxic concentration that reduced cell viability by $50 \%\left(\mathrm{CC}_{50}\right)$ was estimated by nonlinear regression analysis.

\section{Statistical analysis}

One-way ANOVA and the Tukey's test were performed with GraphPad Prism 4 (GraphPad Software, San Diego, California, USA). Values of $p<0.05$ were considered significant.

\section{RESULTS AND DISCUSSION}

\section{Essential oil composition}

The essential oils presented as main components sesquiterpene hydrocarbons (84.3\% for MD-EO and 78.4\% for CS-EO). $E$-caryophyllene $(56.0 \%)$, germacrene D (12.7\%), bicyclogermacrene $(9.2 \%)$ and caryophyllene oxide (3.0\%) were major components of MD-EO employed in this study, as previously reported ${ }^{16}$. The major components of CS-EO were $E$-caryophyllene (22.2\%), germacrene D (19.6\%), bicyclogermacrene $(12.2 \%)$ and $\delta$-cadinene $(6.6 \%)$ (Figure 1 and Table 1). The sesquiterpenes $\alpha$-zingiberene, E-caryophyllene, germacrene $\mathrm{D}$ and bicyclogermacrene have been previously reported as the main components in the essential oil of $C$. sylvestris collected in Brazil ${ }^{11,27,28}$. 
<smiles>C=C1CC/C=C(/C)CCC1C1CC1(C)C</smiles>

1<smiles>[Z]C(C)C(/C=C/C(=C)CC)CC/C(C)=C/C</smiles>

2<smiles>CC1=CC2(CC1)CCC1=CCCC(C1)C2(C)C</smiles>

3

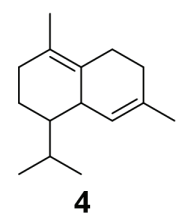

4
Figure 1 - Chemical structures of the major compounds of M. divaricatum and C. sylvestris essential oils: 1) E-caryophyllene; 2) germacrene $D$; 3) bicyclogermacrene; 4) $\delta$-cadinene.

\section{Antileishmanial activity}

The in vitro antileishmanial activity of the MD-EO, CS-EO and $E$-caryophyllene are summarized in Table 2. The essential oils and $E$-caryophyllene were able to inhibit promastigote and amastigote growth. The 50\% inhibitory concentration $\left(\mathrm{IC}_{50}\right)$ of $24.2,29.8$ and $49.9 \mu \mathrm{g} / \mathrm{mL}$ against promastigote forms of $L$. amazonensis were obtained

Table 1 - Composition of the essential oil of $C$. sylvestris leaves.

\begin{tabular}{|c|c|c|c|c|}
\hline Compound name and class*) & $\left.R T[\min ]^{\mathrm{a}}\right)$ & $\left.R l_{\text {exp }}{ }^{\mathrm{b}}\right)$ & $\left.R l_{\text {lit }}{ }^{\circ}\right)$ & Content $\left.[\%]^{d}\right)$ \\
\hline$\delta$-elemene & 22.56 & 1332 & 1337 & 1.5 \\
\hline$\alpha$-cubebene & 23.00 & 1342 & 1345 & 2.4 \\
\hline$\alpha$-longipinene & 23.49 & 1354 & 1351 & 3.6 \\
\hline cyclosativene & 24.22 & 1371 & 1371 & 0.3 \\
\hline isoledene & 24.50 & 1378 & 1377 & 9.0 \\
\hline$\alpha$-copaene & 24.67 & 1382 & 1385 & 0.5 \\
\hline$\beta$-cubebene & 25.00 & 1389 & 1389 & 0.2 \\
\hline cyperene & 25.32 & 1397 & 1398 & 1.8 \\
\hline$\alpha$-gurjunene & 26.06 & 1415 & 1412 & 1.4 \\
\hline E-caryophyllene & 26.58 & 1428 & 1428 & 22.2 \\
\hline$\alpha$-trans-bergamotene & 26.86 & 1436 & 1436 & 1.8 \\
\hline$Z$ - $\beta$-farnesene & 27.10 & 1442 & 1442 & 4.3 \\
\hline$\alpha$-himachalene & 27.29 & 1447 & 1447 & 0.5 \\
\hline$\alpha$-guaiene & 27.43 & 1450 & 1447 & 0.2 \\
\hline$\beta$-santalene & 27.89 & 1462 & 1462 & 2.7 \\
\hline alloaromadendrene & 28.18 & 1469 & 1465 & 0.3 \\
\hline$\gamma$-selinene & 28.66 & 1481 & 1484 & 0.2 \\
\hline$\gamma$-muurolene & 28.78 & 1484 & 1478 & 0.4 \\
\hline germacrene $\mathrm{D}$ & 29.03 & 1491 & 1485 & 19.6 \\
\hline epizonarene & 29.23 & 1496 & 1497 & 0.2 \\
\hline bicylogermacrene & 29.92 & 1513 & 1514 & 12.2 \\
\hline$\alpha$-selinene & 30.06 & 1517 & 1517 & 1.3 \\
\hline hedycaryol & 30.37 & 1525 & 1530 & 1.7 \\
\hline$\delta$-cadinene & 30.75 & 1534 & 1535 & 6.6 \\
\hline trans- $\gamma$-bisabolene & 31.01 & 1541 & 1541 & 0.2 \\
\hline$E$ - $\alpha$-bisabolene & 31.20 & 1546 & 1547 & 0.3 \\
\hline$\alpha$-colocarene & 31.44 & 1552 & 1548 & 0.4 \\
\hline trans-nerolidol & 31.85 & 1562 & 1564 & 0.9 \\
\hline caryophyllene alcohol & 32.11 & 1569 & 1568 & 0.2 \\
\hline longipinanol & 32.41 & 1576 & 1575 & 1.0 \\
\hline viridiflorol & 32.71 & 1584 & 1585 & 0.2 \\
\hline Sesquiterpene hydrocarbons: & & & & 78.4 \\
\hline Oxygenated sesquiterpenes: & & & & 18.4 \\
\hline Others: & & & & 0.8 \\
\hline Not identified: & & & & 2.4 \\
\hline
\end{tabular}

${ }^{\mathrm{a}} R T$ : Retention time determined on the $R t x-5 M S$ capillary column. ${ }^{\mathrm{b}} R I_{\text {exp }}:$ Retention index determined relative to $n$-alkanes $\left(\mathrm{C}_{8}-\mathrm{C}_{20}\right)$ on the Rtx-5MS column. ${ }^{\mathrm{c}} R \mathrm{I}$ : Retention index. ${ }^{\mathrm{d}} \mathrm{C}$ alculated from the peak area relative to the total peak area. Identification: $\mathrm{RI}$, comparison of the retention index with the literature ${ }^{29,30}$; MS, comparison of the mass spectrum with the literature. 
Table 2 - Antileishmanial and cytotoxic activity of essential oils from M. divaricatum, C. sylvestris, E-caryophyllene and amphotericin B.

\begin{tabular}{|c|c|c|c|c|}
\hline Samples & $\begin{array}{l}\text { L. amazonensis } \\
\text { promastigotes } \\
\qquad \mathrm{IC}_{50}(\mu \mathrm{g} / \mathrm{mL})\end{array}$ & $\begin{array}{l}\text { L. amazonensis } \\
\text { amastigotes } \\
\mathrm{IC}_{50}(\mu \mathrm{g} / \mathrm{mL})\end{array}$ & SI & $\begin{array}{c}\text { Macrophages } \\
\text { J774-A1 } \\
\mathrm{CC}_{50}(\mu \mathrm{g} / \mathrm{mL}) \\
\end{array}$ \\
\hline M. divaricatum & $24.2 \pm 2.1$ & $10.7 \pm 2.6$ & ND & $<10$ \\
\hline C. sylvestris & $29.8 \pm 1.1$ & $14.0 \pm 5.9$ & 2.9 & $40.8 \pm 4.5$ \\
\hline E-caryophyllene & $49.9 \pm 2.6$ & $10.7 \pm 0.6$ & 5.8 & $62.1 \pm 1.5$ \\
\hline Amphotericin B & $0.06 \pm 0.0$ & $0.42 \pm 0.08$ & 8.8 & $3.7 \pm 0.3$ \\
\hline
\end{tabular}

Each value represents the mean \pm S.E.M. for three experiments performed in duplicate. $\mathrm{IC}_{50}$ : inhibitory concentration for $50 \%$; $\mathrm{CC}_{50}$ : cytotoxic concentration for $50 \%$; $\mathrm{SI}$ : selective index $\left(\mathrm{CC}_{50}\right.$ macrophages $/ \mathrm{IC}_{50}$ against amastigotes).

for MD-EO, CS-EO and E-caryophyllene, respectively. Furthermore, MD-EO, CS-EO and E-caryophyllene were more active against the amastigote forms than the promastigote ones, displaying $\mathrm{IC}_{50}$ values of the 10.7, 14.0 and $10.7 \mu \mathrm{g} / \mathrm{mL}$, respectively. Amphotericin B had an $\mathrm{IC}_{50}$ of $0.06 \mu \mathrm{g} / \mathrm{mL}$ and $0.42 \mu \mathrm{g} / \mathrm{mL}$ against L. amazonensis promastigote and amastigote forms, respectively, after $72 \mathrm{~h}$ of treatment. These are promising results, given that the essential oils and $E$-caryophyllene proved to be more active against amastigote forms, the proliferative form found inside mammalian host cells.

Several authors showed the leishmanial effect of the essential oils ${ }^{29,30-32}$ and different biological properties have been attributed to a group of sesquiterpenes present in these oils ${ }^{33,34}$.

$E$-caryophyllene (a sesquiterpene hydrocarbon) was the main chemical constituent of the essential oils of M. divaricatum and C. sylvestris. According to Santos et al. ${ }^{15}$, essential oils rich in sesquiterpenes, mainly $E$-caryophyllene, showed variable levels of activity against promastigote forms of Leishmania with $\mathrm{IC}_{50}$ values in the range between 5 and $22 \mu \mathrm{g} / \mathrm{mL}$. Thus, our essential oils showed an antiparasitic potency similar to those described in the literature.

The antileishmanial activity of MD-EO and CS-EO may be associated with the presence of $E$-caryophyllene, as previously suggested in the literature for other essential oils in which $E$-caryophyllene was one of the main components $^{15,29,34,35}$. E-caryophyllene could also interact with other minor components of MD-EO and CS-EO in a synergistic way.

Sesquiterpenes are considered potent skin permeation enhancers, and those with leishmanicidal activity would be very promising candidates for integration in nanocarriers to treat cutaneous leishmaniasis. A mechanism of action based on the Leishmania plasma membrane disrupture is consistent with the reported broad spectrum of sesquiterpene activity against protozoa. It has been shown that the lipophilic components of essential oils may affect layers of polysaccharides, fatty acids, and phospholipids in plasma membranes of Leishmania spp. promastigotes. This then leads to cell lysis and release of macromolecules ${ }^{36}$. In the cytoplasm, these compounds can disrupt the specific metabolic pathways of lipids and proteins or stimulate the depolarization of mitochondrial membranes, which can lead to cell necrosis or apoptosis ${ }^{37,38}$.

The cytotoxicity of MD-EO, CS-EO and $E$-caryophyllene to macrophages J774-A1 was also evaluated (Table 2). The cytotoxicity evaluation of natural products is very important for the development of new antiprotozoal agents ${ }^{39}$. Our results revealed that the cytotoxicity of MD-EO $\left(\mathrm{CC}_{50}<10 \mu \mathrm{g} / \mathrm{mL}\right)$ was higher when compared with CS-EO $\left(\mathrm{CC}_{50}=40.8 \mu \mathrm{g} / \mathrm{mL}\right)$. However, $E$-caryophyllene presented lower cytotoxicity to macrophages J774-A1 with $\mathrm{CC}_{50}$ value equal to $62.1 \mu \mathrm{g} / \mathrm{mL}$.

The cytotoxicity and the antileishmanial activity were compared by using the selectivity index $(\mathrm{SI})$ ratio $\left(\mathrm{CC}_{50}\right.$ for J774-A1 cells/ $/ \mathrm{IC}_{50}$ on intracellular amastigotes). Values greater than 1 are considered more selective for activity against parasites, and a value less than 1 is considered more selective for activity against cells. The SI ratio obtained for the CS-EO and E-caryophyllene was 2.9 and 5.8, in other words they are considered more selective to intracellular amastigotes than to mammalian host cells.

\section{CONCLUSIONS}

The essential oils of $M$. divaricatum and $C$. sylvestris displayed antileishmanial activity against both, promastigote and amastigote forms of Leishmania amazonensis. Their main component $E$-caryophyllene was more active against amastigote forms of L. amazonensis and showed lower toxicity, demonstrating a potential as a drug candidate against Leishmania.

\section{ACKNOWLEDGMENTS}

The authors thank the Scientific Support and Development Program of the Faculdade de Ciências 
Farmacêuticas of the Universidade Estadual Paulista (UNESP), for their financial support.

\section{CONFLICT OF INTERESTS}

The authors declare no conflict of interests.

\section{AUTHORS' CONTRIBUTIONS}

Raquel Regina Duarte Moreira, Caio Humberto Perego, André Gonzaga dos Santos and Flavio Alexandre Carvalho performed and contributed to plant samples collection, extracts preparation and phytochemical study at Universidade Estadual Paulista (UNESP), Faculdade de Ciências Farmacêuticas, Araraquara. Eduardo José Crevelin and Antônio Eduardo Miller Crotti performed the analisys of GC at Universidade de São Paulo (USP), Departamento de Química, Faculdade de Filosofia Ciências e Letras de Ribeirão Preto. Juliana Cogo, Mara Lane Carvalho Cardoso and Celso Vataru Nakamura performed the biological experiment at Universidade Estadual de Maringá, Laboratório de Inovação Tecnológica no Desenvolvimento de Fármacos e Cosméticos e Laboratório de $P \& D$ de Fitoterápicos. All authors contributed equally in analyzing the data and writing the article.

\section{REFERENCES}

1. Torres-Guerrero E, Quintanilla-Cedillo MR, Ruiz-Esmenjaud J, Arenas R. Leishmaniasis: a review. F1000Res. 2017;6:750.

2. World Health Organization. Leishmaniasis. [cited 2018 Jul 20]. Available from: http://www.who.int/mediacentre/factsheets/ fs375/en/

3. Steverding D. The history of leishmaniasis. Parasit Vectors. 2017;10:82.

4. Davis AJ, Murray HW, Handman E. Drugs against leishmaniasis: a synergy of technology and partnerships. Trends Parasitol. 2004;20:73-6.

5. Croft SL, Sundar S, Fairlamb AH. Drug resistance in leishmaniasis. Clin Microbiol Rev. 2006;19:111-26.

6. McConville MJ, Handman E. The molecular basis of Leishmania pathogenesis. Int J Parasitol. 2007;37:1047-51.

7. Carvalho PB, Ferreira EI. Leishmaniasis phytotherapy. Nature's leadership against an ancient disease. Fitoterapia. 2001;72:599618.

8. Bruni N, Stella B, Giraudo L, Della Pepa C, Gastaldi D, Dosio F. Nanostructured delivery systems with improved leishmanicidal activity: a critical review. Int J Nanomedicine. 2017; 12:5289-311.

9. Menezes JP, Guedes CE, Petersen AL, Fraga DB, Veras PS. Advances in development of new treatment for Leishmaniasis. Biomed Res Int. 2015;2015:815023.
10. Tiuman TS, Santos AO, Ueda-Nakamura T, Dias Filho BP, Nakamura CV. Recent advances in leishmaniasis treatment. Int J Infect Dis. 2011;15:e525-32.

11. Estevez Y, Castillo D, Pisango MT, Arevalo J, Rojas R, Alban J, et al. Evaluation of the leishmanicidal activity of plants used by Peruvian Chayahuita ethnic group. J Ethnopharmacol. 2007;114:254-9.

12. Izumi E, Ueda-Nakamura T, Veiga Junior VF, Pinto AC, Nakamura CV. Terpenes from Copaifera demonstrated in vitro antiparasitic and synergic activity. J Med Chem. 2012;55:29943001.

13. Anthony JP, Fyfe L, Smith H. Plant active components - a resource for antiparasitic agents? Trends Parasitol. 2005;21:462-8.

14. Monzote L, Montalvo AM, Almanonni S, Scull R, Miranda M, Abreu J. Activity of the essential oil from Chenopodium ambrosioides grown in Cuba against Leishmania amazonensis. Chemotherapy. 2006;52:130-6.

15. Santos AO, Ueda-Nakamura T, Dias Filho BP, Veiga Junior VF, Pinto AC, Nakamura CV. Effect of Brazilian copaiba oils on Leishmania amazonensis. J Ethnopharmacol. 2008;120:204-8.

16. Moreira RR, Martins GZ, Botelho VT, dos Santos LE, Cavaleiro C, Salgueiro L, et al. Composition and activity against oral pathogens of the essential oil of Melampodium divaricatum (Rich.) DC. Chem Biodivers. 2014;11:438-44.

17. Abab MJ, Bermejo P. Baccharis (Compositae): a review uptade. Arkivoc. 2007;7:76-96.

18. Benedek B, Kopp B, Melzig MF. Achillea millefolium L. s.1. - Is the antiinflamatory activity mediated by protease inhibition? J Ethnopharmacol. 2007;113:312-7.

19. Jeon HJ, Kang HJ, Jung HJ, Kang YS, Lim CJ, Kim YM, et al. Antiinflamatory activity of Taraxacum officinale. J Ethnopharmacol. 2008;115:82-8.

20. Ferreira PM, Costa-Lotufo LV, Moraes MO, Barros FW, Martins AM, Cavalheiro AJ, et al. Folk uses and pharmacological properties of Casearia sylvestris: a medicinal review. An Acad Bras Cienc. 2011;83:1373-84.

21. Council of Europe. European Pharmacopeia. $7^{\text {th }}$ ed. Strasbourg: Council of Europe; 2014.

22. van Den Dool H, Kratz PD. A generalization of the retention index system including linear temperature programmed gas-liquid partition chromatography. J Chromatogr. 1963;11:463-71.

23. Adams RP. Identification of essential oil components by gas chromatography/mass spectrometry. $4^{\text {th }}$ ed. Carol Stream: Allured; 2007.

24. Ueda-Nakamura T, Attias M, Souza W. Megasome biogenesis in Leishmania amazonensis: a morphometric and cytochemical study. Parasitol Res. 2001;87:89-97.

25. Santos AO, Ueda-Nakamura T, Dias Filho BP, Veiga Junior VF, Nakamura CV. Copaiba Oil: an alternative to development of new drugs against leishmaniasis. Evid Based Complement Alternat Med. 2012;2012:898419. 
26. Mosmann T. Rapid colorimetric assay for cellular growth and survival: application to proliferation and cytotoxicity assays J Immunol Methods. 1983;65:55-63.

27. Tininis AG, Assonuma MM, Telascrea M, Perez CC, Silva MR, Favoreto R, et al. Composição e variabilidade química de óleo essencial de Casearia sylvestris SW. Rev Bras Plantas Med. 2006;8:132-6.

28. Bou DD, Lago JH, Figueiredo CR, Matsuo AL, Guadagnin RC, Soares MS, et al. Chemical composition and cytotoxicity evaluation of essential oil from leaves of Casearia sylvestris, its main compound $\alpha$-zingiberene and derivatives. Molecules. 2013;18:9477-87.

29. Ueda-Nakamura T, Mendonça-Filho RR, Morgado-Díaz JA, Maza PK, Dias Filho BP, Cortez DA, et al. Antileishmanial activity of eugenol-rich essential oil from Ocimum gratissimum. Parasitol Int. 2006;55:99-105.

30. Santin MR, Santos AO, Nakamura CV, Dias Filho BP, Ferreira IC, Ueda-Nakamura T. In vitro activity of the essential oil of Cymbopogon citratus and its major component (citral) on Leishmania amazonensis. Parasitol Res. 2009;105:1489-96.

31. Albernaz LC, Paula JE, Romero AR, Silva MR, Grellier P, Mambu $\mathrm{L}$, et al. Investigation of plant extracts in traditional medicine of the Brazilian Cerrado against protozoans and yeasts. J Ethnopharmacol. 2010;131:116-21.
32. Brito AM, Dos Santos D, Rodrigues SA, Brito RG, Xavier-Filho L. Plants with anti-Leishmania activity: Integrative review from 2000 to 2011. Pharmacogn Rev. 2013;7:34-41.

33. Pelissari GP, Pietro RC, Moreira RR. Atividade antibacteriana do óleo essencial de Melampodium divaricatum (Rich.) DC., Asteraceae. Rev Bras Farmacogn. 2010;20:70-4.

34. Le TB, Beaufay C, Nghiem DT, Mingeot-Leclercq M-P, QuetinLeclercq J. In vitro anti-leishmanial activity of essential oils extracted from Vietnamese plants. Molecules. 2017;22:e1071.

35. Monzote L, Alarcón O, Setzer WN. Antiprotozoal activity of essential oils. Agric Conspec Sci. 2012;77:167-75.

36. Di Pasqua R, Betts G, Hoskins N, Edwards M, Ercolini D, Mauriello G. Membrane toxicity of antimicrobial compounds from essential oils. J Agric Food Chem. 2007;55:4863-70.

37. Tariku Y, Hymete A, Hailu A, Rohloff J. Essential-oil composition, antileishmanial, and toxicity study of Artemisia abyssinica and Satureja punctate ssp. Punctate from Ethiopia. Chem Biodivers. 2010;7:1009-18.

38. Armstrong JS. Mitochondrial membrane permeabilization: the sine qua non for cell death. Bioessays. 2006;28:253-60.

39. Brenzan MA, Nakamura CV, Dias Filho BP, Ueda-Nakamura T, Young MC, Cortez DA. Antileishmanial activity of crude extract and coumarin from Calophyllum brasiliense leaves against Leishmania amazonensis. Parasitol Res. 2007;101:715-22. 